Berkala Ilmu Perpustakaan dan Informasi, Vol. 14, No. 1, Juni 2018, Hal. 35-44 DOI: 10.22146/bip.32089

ISSN 1693-7740 (Print), ISSN 2477-0361 (Online)

Tersedia online di https://jurnal.ugm.ac.id/bip

\title{
Pola peminjaman buku di Perpustakaan Universitas Syiah Kuala menggunakan Algoritma Eclat
}

\author{
Muhammad Subianto ${ }^{1}$, Fitriana $\mathrm{AR}^{2}$, dan Meildha Hijriyana $\mathbf{P}^{1}$ \\ ${ }^{1}$ Jurusan Informatika, FMIPA Universitas Syiah Kuala \\ ${ }^{2}$ Program Studi Statistika FMIPA Universitas Syiah Kuala \\ Email: subianto@unsyiah.ac.id
}

Naskah diterima: 6 Januari 2018, direvisi: 28 Februari 2018, disetujui: 18 April 2018

\begin{abstract}
ABSTRAK
Pendahuluan. UPT Perpustakaan Unsyiah adalah salah satu fasilitas dari Universitas Syiah Kuala yang menyediakan layanan peminjaman buku kepada pemustaka. Setiap informasi peminjaman buku disimpan oleh perpustakaan sehingga menghasilkan data peminjaman buku dalam ukuran besar.

Metode penelitian. Penelitian ini bertujuan untuk menentukan pola relevansi antara subjek buku dengan program studi peminjam, serta menentukan pola peminjaman buku berdasarkan buku-buku yang sering dipinjam secara bersamaan. Pola tersebut dapat ditemukan menggunakan salah satu metode data mining yaitu association rules mining dengan algoritma Eclat. Algoritma Eclat menggunakan vertikal format dari dataset untuk melakukan perpotongan TID list antar item dalam menentukan support count sehingga proses pencarian frequent itemset lebih cepat. Adapun tahapan penelitian yaitu pengumpulan data, pre-processing, proses algoritma Eclat, hasil algoritma Eclat dan analisis hasil.

Data analisis. Tercatat ada sebanyak 122.945 data peminjaman buku dari tahun 2007 hingga 2015 yang digunakan pada penelitian ini. Berdasarkan data tersebut dapat diketahui pola perilaku peminjaman buku yang biasanya terjadi di UPT Perpustakaan Unsyiah oleh peminjam, khususnya mahasiswa Unsyiah.

Hasil dan Pembahasan. Algoritma Eclat menghasilkan pola subjek buku dan program studi yang paling sering berulang dari beberapa tahun data penelitian yaitu Accounting dengan Akuntasi (S1) serta Chemistry dengan Pendidikan Kimia (S1).

Kesimpulan dan Saran. Hasil analisis pola subjek buku dan program studi yang telah ditemukan menunjukkan bahwa kebiasaan mahasiswa Unsyiah meminjam buku di perpustakaan sesuai dengan program studinya. Sedangkan untuk pola antar buku, algoritma Eclat menemukan keterkaitan antar buku dan paling sering berulang dari beberapa periode tahun data penelitian yaitu kode buku yaitu 12311 (Dasar-dasar evaluasi pendidikan) dengan 42265 (Pengantar evaluasi pendidikan).
\end{abstract}

Kata Kunci: Association rules mining; Eclat; Perpustakaan

\section{ABSTRACT}

Introduction. UPT Unsyiah Library is one of the facilities in Syiah Kuala University which provides book lending service to users. The library collects all information and has expanded a big data of book lending.

Data Collection Method. This research aims to determine the relevance pattern between the book subject and the borrower's program of study, and to determine the pattern of book borrowing based on books that are often borrowed simultaneously. The pattern can be found using one of the methods of data mining that is the association rules mining with Eclat algorithm. Eclat algorithm uses vertical format of dataset to intersect TID list between items in determining support count so that the process of searching frequent itemset is faster.

Analysis Data. There are 122.945 book lending data from 2007 to 2015 used in this study. These data show the borrowers' behavior pattern of book lending behavior in UPT Library Unsyiah, especially the borrowers who are student of this university. 
Results and Discussions. The Eclat algorithm produces the most frequent and repeatable pattern of book subjects and program of studies from several years of research data, which are Accounting book subjects with its program of study (S1) and Chemistry book subjects with Chemistry Education program of study (S1).

Conclusions. The analysis result for the book subject pattern and program of studies shows that the habit of Unsyiah students in borrowing books from the library is accordingly to their program of studies. As for the patterns between books, Eclat algorithm found linkage between books and most often repeated from several periods of years of research data is the book code of 12311 (Fundamentals of educational evaluation) with 42265 (Introduction to evaluation of education).

Keywords: Association rules mining; Eclat; Library

\section{A. PENDAHULUAN}

Universitas Syiah Kuala (Unsyiah) adalah lembaga pendidikan yang memiliki perpustakaan sebagai salah satu fasilitas yang sangat penting. Unit Pelayanan Teknis Perpustakaan Unsyiah bernama Perpustakaan Prof. Dr. H. Abdullah Ali, M.Sc. yang telah berdiri sejak tahun 1970. UPT Perpustakaan Unsyiah berfungsi sebagai media penyedia sumber ilmu pengetahuan dan informasi, serta membantu proses belajar mengajar bagi pengunjungnya. Pengunjung yang datang ke perpustakaan meliputi mahasiswa, dosen, pegawai dan tamu.

UPT Perpustakaan Unsyiah memiliki koleksi tercetak sebanyak 75.114 judul buku atau sebanyak 136.925 eksemplar. Koleksi buku UPT Perpustakaan Unsyiah terdiri dari buku teks, terbitan berkala (jurnal), laporan akhir, skripsi, tesis, disertasi, majalah, buku referensi, laporan penelitian, CD-ROM dan dokumentasi (Renstra UPT Perpustakaan Unsyiah, 2014). Koleksi tersebut dapat dipinjam dan beberapa hanya dapat dibaca di perpustakaan.

Perpustakaan setiap hari melakukan kegiatan peminjaman buku oleh peminjam, sehingga menghasilkan kumpulan data yang besar. Tercatat ada sebanyak 122.945 data peminjaman buku oleh mahasiswa Unsyiah pada periode tahun 2007 hingga tahun 2015. Kumpulan data tersebut diolah pihak perpustakaan sebagai laporan peminjaman buku dan pembanding tingkat kinerja setiap tahun. Data peminjaman buku tersebut kemudian disimpan menjadi kumpulan data yang besar. Padahal jika dilakukan penelitian lebih lanjut terhadap data peminjaman buku sebelumnya, akan dihasilkan informasi yang bermanfaat bagi perpustakaan.

Informasi yang baik dan tepat akan menjadi salah satu cara dalam mengelola perpustakaan dengan baik. Informasi tersebut dapat mendasari pengambilan keputusan yang tepat dalam meningkatkan layanan perpustakaan. Misi pertama perpustakaan dalam Renstra UPT Perpustakaan Unsyiah (2014) menyatakan, menyediakan kebutuhan koleksi yang relevan dengan kebutuhan pemustaka. Maka perpustakaan memerlukan informasi tentang perilaku peminjaman buku yang telah terjadi sebelumnya, untuk mengetahui relevansi buku yang ada di perpustakaan terhadap kebutuhan pengunjung (pemustaka). Menurut Rodin (2015) salah satu tugas perpustakaan Perguruan Tinggi adalah melakukan pelayanan kepada seluruh sivitas akademika di perguruan tinggi. Sebagai sebuah lembaga yang melakukan aktifitas pelayanan, maka perpustakaan berkewajiban untuk senantiasa meningkatkan kualitas layanannya agar dapat memenuhi kebutuhan para pemustaka.

Begitu banyaknya informasi peminjaman buku tiap bulan akan mempengaruhi pembentukan pola transaksi peminjaman berdasarkan bulan dan tahun peminjaman. MenurutAprilina et al. (2015), pola peminjaman yang sering muncul pada bulan-bulan di tahun yang sama kemudian pola tersebut akan terjadi pada bulan pada tahun yang sama dimana hal ini menunjukkan bahwa pola tersebut konsisten. Wandi, Hendrawan, \& Mukhlason (2012) membahas mengenai penggunaan algoritma $A$ - 
Priori untuk menghasilkan rekomendasi buku dari transaksi peminjaman buku yang ada dimana minimum supportnya diantara 1 sampai dengan 4, dan panjang itemset berbanding terbalik dengan jumlah minimum support, semakin besar nilai minimum support yang diberikan semakin kecil panjang jumlah itemset yang terbentuk. Azwar (2014) menganalisa pola peminjaman buku perpustakaan menggunakan algoritma A-Priori. Analisa peminjaman buku dilakukan dengan aturan asosiatif yaitu untuk mengetahui besarnya kemungkinan pemustaka untuk meminjam buku dan memperoleh polapola peminjam di perpustakaan. Dari aturan asosiatif diperoleh bahwa buka Agama dan buku TIK mejadi buku yang paling sering dipinjam secara bersamaan oleh pemustaka.

Oleh karena itu, transaksi peminjaman buku di perpustakaan dapat menghasilkan informasi yang berguna untuk meningkat pelayanan perpustakaan. Informasi tersebut misalnya menemukan pola hubungan antara program studi peminjam dengan subjek buku yang telah dipinjam. Subjek buku adalah jenis buku yang berkaitan dengan judul, tema dan isi buku. Penemuan pola dapat memberikan pengetahuan tentang kebiasaan perilaku minat baca, serta relevansi kebutuhan peminjam terhadap koleksi buku di perpustakaan. Informasi lain yang juga dapat diperoleh yaitu pola peminjaman bukubuku yang sering dipinjam secara bersamaan oleh peminjam di perpustakaan.

Dengan banyaknya kebutuhan buku yang diperlukan untuk kegiatan belajar mengajar dan ketersediaan subjek buku sesuai dengan perkuliahan di masing-masing program studi maka UPT Perpustakaan Unsyiah perlu mengkaji kebutuhan subjek buku yang sesuai dengan program studi di Universitas Syiah Kuala. Kajian ini diharapkan akan terpenuhinya ketersediaan subjek buku bagi peminjam di lingkungan Universitas Syiah Kuala.

Oleh karena itu penulis ingin mencari pola relevansi antara subjek buku dengan program studi peminjam, serta menentukan pola peminjaman buku berdasarkan buku-buku yang sering dipinjam secara bersamaan dari data peminjaman buku UPT. Perpustakaan Unsyiah.

Pengolahan dan analisa lebih lanjut pada data peminjaman buku dilakukan dengan Data Mining, yaitu Association Rules Mining, dengan menggunakan algoritma Equivalent Class Transformation (Eclat). Algoritma Eclat digunakan untuk menemukan pola peminjaman buku oleh mahasiswa di perpustakaan Unsyiah. Informasi tersebut dapat berguna sebagai salah satu referensi dalam mengambil kebijakan yang tepat untuk meningkatkan pelayanan perpustakaan.

\section{B. TINJAUAN PUSTAKA}

Perpustakaan adalah suatu lembaga yang memberikan fasilitas bagi pengunjung berupa sumber informasi, sumber ilmu pengetahuan dan juga membantu kegiatan belajar mengajar sehingga pengunjung dapat menemukan pengetahuan yang mereka dibutuhkan. Layanan utama yang biasanya perpustakaan sediakan bagi pengunjung berupa membaca buku di perpustakaan dan peminjaman buku bagi pengunjung yang telah terdaftar (Wandi et al., 2012).

Setiap perpustakaan memiliki data transaksi peminjaman buku. Kebanyakan perpustakaan telah memiliki penyimpanan data peminjaman buku (database) yang sederhana maupun yang besar. Untuk mendapatkan informasi dari data yang besar, diperlukan analisa dengan cara khusus yaitu menggunakan teknik data mining (Supardi, Ratnawati, \& Mahmudy, 2014).

\section{Data Mining}

Data mining menurut Han et al. (2012) merupakan suatu proses menemukan pengetahuan penting dari kumpulan besar data yang telah disimpan dalam database. Pengetahuan tersebut tidak dapat ditemukan hanya dengan cara sederhana. Data mining menggunakan teknik (metode) tertentu untuk menemukan pengetahuan diantaranya klasifikasi, clustering dan analisa keterkaitan.

Menurut Slimani \& Lazzez (2014) tugas data mining dapat dikelompokkan ke dalam dua kategori yaitu: 
1. Predictive mining berkaitan dengan metode klasifikasi, regresi dan deviation detection.

2. Descriptive mining akan menurunkan dan menyelidiki pola-pola (kolerasi, trend, cluster) hubungan penting dari kumpulan data. Metode utama dari descriptive mining yaitu clustering, association rules dan sequential mining.

\section{Association Rules Mining}

Association rules mining adalah metode data mining yang menggunakan hubungan suatu item dengan item lainnya yang terdapat di dalam itemset untuk memprediksi pola dari kumpulan data(Olson \& Delen, 2008).

Slimani \& Lazzez (2014) menyatakan association rules didefinisikan ke dalam tiga pola, yaitu:

a. Frequent itemset mining, proses ini dapat dilakukan pada data transaksi, relasional, dataset atau jenis data lain untuk mencari frequent itemset. Algoritma association rules untuk mencari frequent itemset diantaranya yaitu Apriori, FP-growth dan Eclat.

b. Sequential pattern mining, proses ini dapat menemukan pola berurutan (frequent subsequences) dari item yang sering muncul di dalam kumpulan data. Beberapa algoritma association rules untuk mencari sequential pattern mining yaitu SPADE, GSP dan PrefixSpan.

c. Structrured pattern mining, proses ini mencari frequent substructures di dalam sebuah substructured dataset.

Han et al. (2012) menyatakan frequent itemset diperoleh dengan mencari nilai support dan confidence dari itemset sebagai berikut:

\section{a. Support:}

$\operatorname{support}(A \rightarrow B)=P(A \cap B)=\frac{\text { Total Transaksi } A \text { dan } B}{\text { Total Seluruh Transaksi }}$

\section{b. Confidence:}

confidence $(A \rightarrow B)=P(B \mid A)=\frac{\text { Total Transaksi } A \text { dan } B}{\text { Total Transaksi } A}$

Semua aturan asosiasi yang dihasilkan memiliki nilai confidence lebih besar atau sama dengan nilai all-confidence. Nilai all-confidence dari itemset dapat ditentukan dengan rumus:

$$
\text { all-confidence }(X)=\frac{\operatorname{Support}(X)}{\max _{I \in X} \operatorname{support}(I)}
$$

Penyebut adalah nilai support maksimal item yang berasal dari subset $X$, tidak termasuk himpunan kosong dan improper subset. Nilai maksimal akan diperoleh saat subset dari $X$ terdiri dari satu item. All-confidence merupakan salah satu alternatif untuk mengukur aturan asosiasi(Omiecinski, 2003).

\section{Algoritma Eclat (Equivalence Class Transformation)}

Algoritma Eclat melakukan pencarian frequent itemset dari kumpulan data (dataset). Algoritma Eclat diperkenalkan oleh Zaki, Parthasarathy, Ogihara, \& Li (1997) yaitu algoritma yang melakukan kegiatan pengelompokan item yang sama berdasarkan kriteria tertentu ke dalam kelas (Equivalence class). Kelas yang sama tersebut didapatkan dari partisi suatu himpunan. Equivalence class pada algoritma Eclat dibangun dengan kelas berbasis prefiks. Algoritma Eclat mempunyai proses lebih cepat, karena dataset akan dipresentasikan dalam vertical format dari dataset.

MenurutLi, Liu, Liao, \& Choudhary (2006) algoritma Eclat akan mengubah bentuk dataset horizontal menjadi vertikal transaksi id-list (tidlist) dari itemset. Tid-list (TID) dari itemset diperoleh dari urutan ID data transaksi yang memuat itemset tersebut.

Borgelt (2003) menyatakan algoritma Eclat menentukan support dari itemset menggunakan daftar transaksi id-list dari transaksi yang memuat itemset. Perpotongan tid-list secara langsung antar itemset dapat terjadi karena penyajian dataset oleh Eclat secara vertikal. Maka perhitungan support count untuk menemukan frequent itemset menggunakan algoritma Eclat akan lebih cepat. Itemset pada algoritma Eclat diurutkan sesuai dengan kata atau huruf pada kamus (Lexicographic).

Algoritma Eclat melakukan strategi pencarian item dari khusus ke umum (Bottom Up) menggunakan Depth First Search untuk membangkitkan kandidat itemset dalam 
menemukan frequent itemset. Eclat hanya akan memeriksa (scan) dataset sebanyak satu kali, tidak melakukannya berulang-ulang karena menggunakan vertikal tid-list, sehingga tid-list sudah memberikan informasi tentang support count dari itemset (Kaur \& Grag, 2014).

\section{METODE PENELITIAN \\ Pengumpulan Data}

Data yang digunakan yaitu data peminjaman buku di UPT. Perpustakaan Unsyiah. Data yang tercatat sebanyak 122.945 yang terkumpul dari tahun 2007 hingga 2015. Atribut data peminjaman buku yang digunakan dapat dilihat pada Tabel 1.

\section{Pre-processing}

Beberapa data peminjaman buku yang tidak memiliki informasi lengkap akan dihapus. Jumlah seluruh record dataset setelah cleaning data yaitu 103.055. Kemudian subjek buku diubah menjadi subjek utama dan kemudian dilakukan transformasi data dengan memisahkan dataset berdasarkan tahun peminjaman buku dan beberapa periode tahun peminjaman buku. Pencarian pola relevansi subjek buku dan program studi peminjam membutuhkan informasi diantaranya yaitu subjek buku dan program studi peminjam (Tabel 2).

Penentuan pola peminjaman buku-buku sering dipinjam bersamaan memerlukan informasi NIM, tanggal peminjaman, kode buku (biblio_id) dan judul buku. Dataset peminjaman setiap buku yang telah ada akan dibentuk menjadi satu kegiatan peminjaman berdasarkan NIM peminjam dan tanggal peminjaman yang sama (Tabel 3).

\section{Proses Algoritma Eclat}

Data yang telah melalui tahap preprocessing kemudian dilakukan pencarian frequent itemset. Itemset yang telah memenuhi nilai minimum support akan menjadi frequent itemset. Selanjutnya perangkat lunat R (R Core Team, 2017) dengan library arules (Hahsler, Buchta, Gruen, \& Hornik, 2018) digunakan dalam membantu penelitian ini.

\section{Analisis Hasil}

Pola subjek buku dan program studi yang ditemukan akan dilihat memiliki hubungan atau tidak memiliki hubungan, berdasarkan kesesuaian subjek buku dengan mata kuliah dari program studi mahasiswa, kesesuaian subjek buku dengan topik program studi (bidang minat) mahasiswa serta pola yang muncul berulang-ulang pada beberapa tahun penelitian. Kemudian akan dilihat pola peminjaman bukubuku yang sering dipinjam secara bersamaan oleh mahasiswa dan muncul berulang-ulang dibeberapa periode tahun penelitian.

\section{HASIL DAN PEMBAHASAN Analisa Pola Relevansi Subjek Buku dengan Program Studi}

Subjek buku di perpustakaan Unsyiah adalah informasi jenis buku atau kategori dari buku. Jenis buku yang dimaksudkan berkaitan dengan judul, topik dan isi buku tersebut. Subjek buku akan memudahkan proses pengelompokan dan pencarian judul-judul buku yang sejenis di perpustakaan Unsyiah. Dalam menentukan subjek buku yang sering dipinjam oleh mahasiswa akan diperoleh melalui pola antara subjek buku dan program studi peminjam. Pola tersebut diperoleh dengan algoritma Eclat dari itemset yang telah memenuhi nilai minimum support, sehingga menjadi frequent itemset. Minimum support untuk menemukan pola subjek buku dengan program studi dapat dilihat pada Tabel 4.

Pengujian data pada tiap tahun dilakukan dengan minimum support $0.5 \%$ hingga $0.2 \%$. Minimum support $0.5 \%$ atau $1 \%$ dipilih karena 2-frequent itemset yang dihasilkan pada masingmasing tahun dari 2007 hingga 2015 maksimal mendekati 10 frequent itemset. Hasil 2-frequent itemset dengan jumlah maksimal 10 adalah itemset dengan support tertinggi untuk pola subjek buku dan prodi pada masing-masing tahun. Berdasarkan Tabel 4 dapat diketahui semakin besar dataset maka semakin besar waktu proses pencarian frequent itemset.

Adapun pola yang akan dianalisis pada setiap tahun yaitu 2-frequent itemset yang ditemukan dengan minimum support yang telah 
ditentukan sebelumnya pada Tabel 4. Berdasarkan Tabel 4 hasil pola subjek buku dan prodi tahun 2012 hingga 2015 dapat dilihat pada Tabel 5.

Terdapat beberapa pola yang diperoleh lebih dari dua perulangan pada tahun 2007 hingga tahun 2015, yaitu subjek buku ACCOUNTING dengan program studi peminjam Akuntansi (S1), subjek buku CHEMISTRY dengan program studi peminjam adalah Pendidikan Kimia (S1), subjek buku BIOLOGY dengan prodi peminjam adalah Pendidikan Biologi (S1) dan beberapa pola yang lainnya. Pola pada Tabel 5 memperlihatkan kebanyakan mahasiswa di perpustakaan Unsyiah meminjam buku yang berhubungan (sesuai) dengan mata kuliah program studinya masing-masing. Pola yang terdapat pada tabel tersebut juga memperlihatkan bahwa kebanyakan subjek buku yang dipinjam oleh mahasiswa Unsyiah merupakan mata kuliah dasar yang bersifat wajib. Pola tersebut memperlihatkan kebiasaan peminjaman buku yang sering dilakukan oleh mahasiswa Unsyiah di perpustakaan beberapa tahun sebelumnya.

\section{Analisa Pola Peminjaman Buku yang Sering Dipinjam Bersamaan}

Persebaran (rentang) data merupakan salah satu faktor yang akan mempengaruhi nilai minimum support untuk menemukan frequent itemset. Semakin besar record dataset dan semakin besar persebaran data maka akan semakin rendah nilai minimum support dan minimum confidence. Berdasarkan Tabel 6. dapat diketahui bahwa sebesar $49 \%$ adalah data peminjaman satu buku. Kemudian data peminjaman dua buku sebesar 33\%. Jika mencari rekomendasi buku hingga lebih dari tiga buku maka kemungkinan tidak dapat ditemukan frequent itemset.

Penentuan minimum support dipilih dengan melakukan uji coba minimum support $0.01 \%$ hingga $0.07 \%$. Pemilihan minimum support didasari oleh perbedaan jumlah frequent itemset (pola) yang dihasilkan oleh setiap dataset. Minimum support tersebut dipilih karena 2frequent itemset berjumlah maksimal mendekati 10 frequent itemset untuk setiap periode tahun dapat ditemukan dengan minimum support $0.02 \%, 0.03 \%, 0.04 \%$ atau $0.06 \%$ (Tabel 7).

Berdasarkan uji coba minimum support semakin besar jumlah record dataset maka akan semakin kecil nilai minimum support yang memenuhi maksimal mendekati 10 frequent itemset. Dan semakin tinggi nilai minimum support maka semakin kecil jumlah frequent itemset yang dihasilkan dan semakin cepat waktu proses pencarian frequent itemset. Pola rekomendasi dua buku yang dianalisis adalah pola yang ditemukan dengan minimum support yang telah ditentukan sebelumnya pada Tabel 7 untuk masing-masing periode tahun.

Berdasarkan Tabel 8, pola buku-buku yang paling sering muncul di beberapa periode peminjaman buku adalah judul buku "Dasardasar evaluasi pendidikan" bersama dengan "Pengantar evaluasi pendidikan". Pola tersebut muncul berulang sebanyak tiga perulangan (tiga periode tahun) dari empat periode. Buku-buku yang terdapat pada Tabel 8 memperlihatkan keterkaitan antara dua buku yang sering dipinjam secara bersamaan. Buku-buku yang terdapat pada Tabel 8 dapat menjadi saran rekomendasi atau alternatif buku yang berkaitan karena biasanya sering dipinjam secara bersamaan oleh mahasiswa di perpustakaan Unsyiah.

\section{E. KESIMPULAN}

Hasil analisis pola subjek buku dan program studi yang telah ditemukan menunjukkan bahwa kebiasaan mahasiswa Unsyiah meminjam buku di perpustakaan selalu berhubungan dengan program studi mahasiswa tersebut. Terdapat dua pola subjek buku dan prodi yang paling sering berulang. Pola pertama yaitu subjek buku ACCOUNTING dengan mahasiswa peminjam dari program studi Akuntansi (S1) yang ditemukan pada tujuh tahun data peminjaman buku dari sembilan tahun data penelitian. Pola kedua yaitu subjek buku CHEMISTRY dengan mahasiswa peminjam dari program studi Pendidikan Kimia (S1) yang ditemukan pada lima tahun data peminjaman buku dari sembilan 
tahun data penelitian. Sedangkan untuk pola antar buku, algoritma Eclat menemukan keterkaitan antar buku dan paling sering berulang dari beberapa periode tahun data penelitian yaitu buku "Dasar-dasar evaluasi pendidikan" (12311) dengan buku "Pengantar evaluasi pendidikan" (42265).

\section{DAFTAR PUSTAKA}

Aprilina, M. N. Q., Wiranto, \& Widodo. (2015). Analisa konsistensi pola peminjaman buku menggunakan algoritma FP-Groth. In M. A. Muslim, A. Purwinarko, F. A. Setyawan, B. Prasetiyo, A. T. Putra, E. Listiana, U. I. Larasati (Eds.), Seminar Nasional Ilmu Komputer (SNIK 2015) (pp. 227-234). Semarang, 10 Oktober 2015.

Azwar, A. (2014). Analisa pola peminjaman buku perpustakaan menggunakan algoritma apriori. Jurnal Edik Informatika, Vol 1, No, $52-62$.

Borgelt, C. (2003). Efficient Implementations of Apriori and Eclat. In Proc. 1st IEEE ICDM Workshop on Frequent Item Set Mining Implementations (FIMI 2003, Melbourne, FL). CEUR Workshop Proceedings 90 (p. 90).

Hahsler, M., Buchta, C., Gruen, B., \& Hornik, K. (2018). arules: Mining Association Rules and Frequent Itemsets. Retrieved from https://cran.r-project.org/package=arules

Han, J., Kamber, M., \& Pei, J. (2012). Data mining concepts and techniques (3rd ed.). Morgan Kaufmann.

Kaur, M., \& Grag, U. (2014). ECLAT Algorithm for Frequent Itemsets Generation. International Journal of Computer Systems, 1(3), 82-84.

Li, J., Liu, Y., Liao, W., \& Choudhary, A. (2006). Parallel data mining algorithms for association rules and clustering.

Olson, D. L., \& Delen, D. (2008). Advanced data mining techniques (1st ed.). Springer Publishing Company, Incorporated.
Omiecinski, E. R. (2003). Alternative interest measures for mining associations in databases. IEEE Transactions on Knowledge and Data Engineering, 15(1), $57-69$. h t t p s : / / d o i.org / http://doi.ieeecomputersociety.org/10.1109 /TKDE.2003.1161582

R Core Team. (2017). R: A language and environment for statistical computing. Vienna, Austria. Retrieved from https://www.r-project.org/

Renstra UPT. Perpustakaan Unsyiah. (2014). Dokumen Rencana Strategis (Renstra) 2015-2018 UPT. Perpustakaan Unsyiah. UPT. Perpustakaan Unsyiah. Banda Aceh.

Rodin, R. (2015). Urgensi kualitas pelayanan perpustakaan perguruan tinggi. Al-Kuttab : Jurnal Perpustakaan Dan Informasi, 2(1), 1-20. Retrieved from http://ejournal.perpustakaanstainpsp.net/index.php /alkuttab/article/view/49

Slimani, T., \& Lazzez, A. (2014). Efficient analysis of pattern and association rule mining approaches. International Journal of Information Technology and Computer Science, 6(3), 70-81. Retrieved from http://arxiv.org/abs/1402.2892

Supardi, Ratnawati, D. E., \& Mahmudy, W. F. (2014). Pengenalan pola transaksi sirkulasi buku pada database perpustakaan menggunakan algoritma generalized sequential pattern. Jurnal Mahasiswa PTIIK Universitas Brawijaya, 4(11), 1-8.

Wandi, N., Hendrawan, R. A., \& Mukhlason, A. (2012). Pengembangan sistem rekomendasi penelusuran buku dengan penggalian association rule menggunakan algoritma apriori (Studi Kasus Badan Perpustakaan dan Kearsipan Provinsi Jawa Timur). Jurnal TeknikITS, 1(Sept, 2012), 445-449.

Zaki, M. J., Parthasarathy, S., Ogihara, M., \& Li, W. (1997). New algorithms for fast discovery of association rules. In Proceedings of the Third International Conference on Knowledge Discovery and Data Mining (pp. 283-286). AAAI Press. Retrieved from http://dl.acm.org/ citation.cfm? $\mathrm{id}=3001392.3001454$ 


\section{DAFTAR TABEL}

Tabel 1. Informasi atribut data peminjaman buku

\begin{tabular}{ll}
\hline Atribut Data & Penjelasan \\
\hline NIM & NIM dari peminjam \\
ID Anggota & ID peminjam buku \\
Judul & Judul buku \\
Subject & Jenis buku (judul, tema dan isi buku) \\
biblio_id & Kode judul buku \\
loan_date & Tanggal peminjaman buku \\
due_date & Tanggal pengembalian buku \\
Fakultas & Fakultas dari peminjam \\
Jurusan & Jurusan dari peminjam \\
Prodi & Program studi dari peminjam \\
\hline
\end{tabular}

Tabel 2. Perwakilan dataset subject buku dan prodi

\begin{tabular}{cll}
\hline No & Subject & Program Studi \\
\hline 1 & ACCOUNTING & Perpajakan (D3) \\
2 & AEROBICS & Pendidikan Penjaskesrek (S1) \\
3 & AGRIBUSINESS & Agribisnis (S1) \\
4 & BIOCHEMISTRY & Peternakan (S1) \\
5 & BIOLOGY & Ilmu Tanah (S1) \\
\hline
\end{tabular}

Tabel 3. Perwakilan dataset rekomendasi buku

\begin{tabular}{ll}
\hline No & Kode Buku \\
\hline 1 & $9488,36591,39668$ \\
2 & 17935,17850 \\
3 & 30829,53527 \\
4 & 31274,31274 \\
5 & $165,8222,33427$ \\
\hline
\end{tabular}

Tabel 4. Minimum support dari pola subject buku dan prodi.

\begin{tabular}{rrccc}
\hline Tahun & Record & $\begin{array}{c}\text { Minimum } \\
\text { Support }(\%)\end{array}$ & $\begin{array}{c}\text { Waktu } \\
\text { (detik) }\end{array}$ & $\begin{array}{c}\text { Jumlah 2-Frequent } \\
\text { itemset }\end{array}$ \\
\hline 2007 & 577 & 1.0 & 0.00 & 8 \\
2008 & 4.174 & 0.5 & 0.00 & 7 \\
2009 & 4.189 & 0.5 & 0.00 & 10 \\
2010 & 4.163 & 0.5 & 0.00 & 7 \\
2011 & 4.560 & 0.5 & 0.00 & 10 \\
2012 & 7.116 & 0.5 & 0.00 & 8 \\
2013 & 12.654 & 0.5 & 0.00 & 8 \\
2014 & 28.515 & 0.5 & 0.01 & 5 \\
2015 & 33.356 & 0.5 & 0.01 & 5 \\
\hline
\end{tabular}


Tabel 5. Hasil frequent itemset dari subject buku dan program studi menggunakan algoritma Eclat

\begin{tabular}{|c|c|c|c|c|c|c|}
\hline Tahun & Subject Buku & $\begin{array}{l}\text { Program Studi } \\
\text { Peminjam }\end{array}$ & $\begin{array}{c}\text { Support } \\
(\%)\end{array}$ & $\begin{array}{c}\text { all } \\
\text { confidence }\end{array}$ & $\begin{array}{l}\text { Hubungan } \\
\text { prodi dan } \\
\text { subject }\end{array}$ & $\begin{array}{c}\text { Jumlah } \\
\text { Ulangan } \\
\text { Pola }\end{array}$ \\
\hline \multirow{8}{*}{2012} & BIOLOGY & Pendidikan Biologi (S1) & 1.80 & 27 & $\checkmark$ & 4 \\
\hline & CHEMISTRY & Pendidikan Kimia (S1) & 1.50 & 27 & $\checkmark$ & 5 \\
\hline & COMMUNICATION & Ilmu Komunikasi & 0.96 & 36 & $\checkmark$ & 3 \\
\hline & CALCULUS & Ilmu Matematika (S1) & 0.75 & 21 & $\checkmark$ & 2 \\
\hline & PHYSICS & Ilmu Fisika (S1) & 0.73 & 17 & $\checkmark$ & 2 \\
\hline & CHEMISTRY & Ilmu Kimia (S1) & 0.62 & 13.06 & $\checkmark$ & - \\
\hline & CHEMISTRY & Ilmu Biologi (S1) & 0.51 & 10.67 & $\checkmark$ & - \\
\hline & CHEMISTRY & Pendidikan Biologi (S1) & 0.51 & 7.7 & $\checkmark$ & - \\
\hline \multirow{8}{*}{2013} & CHEMISTRY & Pendidikan Kimia (S1) & 1.80 & 31 & $\checkmark$ & 5 \\
\hline & BIOCHEMISTRY & Kedokteran Hewan (S1) & 1.00 & 25 & $\checkmark$ & 2 \\
\hline & BIOLOGY & Pendidikan Biologi (S1) & 0.72 & 15 & $\checkmark$ & 4 \\
\hline & MANAGEMENT & Manajemen (S1) & 0.67 & 18 & $\checkmark$ & 2 \\
\hline & PATHOLOGY & Pendidikan Dokter (S1) & 0.64 & 12 & $\checkmark$ & - \\
\hline & COMMUNICATION & Ilmu Komunikasi & 0.55 & 27 & $\checkmark$ & 3 \\
\hline & ACCOUNTING & Akuntansi (S1) & 0.53 & 15 & $\checkmark$ & 7 \\
\hline & ELECTROMAGNET & Teknik Elektro (S1) & 0.51 & 22 & $\checkmark$ & - \\
\hline \multirow{5}{*}{2014} & CHEMISTRY & Pendidikan Kimia (S1) & 1.10 & 23 & $\checkmark$ & 5 \\
\hline & ACCOUNTING & Akuntansi (S1) & 0.94 & 19.6 & $\checkmark$ & 7 \\
\hline & COMMUNICATION & Ilmu Komunikasi & 0.74 & 25 & $\checkmark$ & 3 \\
\hline & BIOCHEMISTRY & Kedokteran Hewan (S1) & 0.63 & 11.3 & $\checkmark$ & 2 \\
\hline & BIOLOGY & Pendidikan Biologi (S1) & 0.53 & 18 & $\checkmark$ & 4 \\
\hline \multirow{5}{*}{2015} & ACCOUNTING & Akuntansi (S1) & 1.30 & 22 & $\checkmark$ & 7 \\
\hline & COMMUNICATION & Ilmu Komunikasi & 1.00 & 27 & $\checkmark$ & 3 \\
\hline & CHEMISTRY & Pendidikan Kimia (S1) & 0.78 & 19.6 & $\checkmark$ & 5 \\
\hline & DENTISTRY & Kedokteran Gigi & 0.55 & 20 & $\checkmark$ & - \\
\hline & TAXATION & Akuntansi (S1) & 0.53 & 8.9 & $\checkmark$ & 2 \\
\hline
\end{tabular}

Keterangan tanda :

$\checkmark$ Subject buku sesuai dengan mata kuliah program studi

Tabel 6. Persebaran data peminjaman buku berdasarkan jumlah peminjaman buku.

\begin{tabular}{ccr}
\hline No & Jumlah Buku & Jumlah Peminjaman \\
\hline 1 & 8 & 10 \\
2 & 7 & 3 \\
3 & 6 & 22 \\
4 & 5 & 190 \\
5 & 4 & 347 \\
6 & 3 & 10.204 \\
7 & 2 & 20.243 \\
8 & 1 & 29.718 \\
\hline \multicolumn{3}{c}{ Jumlah dataset semua tahun $=60.737$} \\
\hline
\end{tabular}


Tabel 7. Jumlah frequent itemset dari pola rekomendasi dua buku dengan algoritma Eclat

\begin{tabular}{ccccc}
\hline Tahun & Record & $\begin{array}{c}\text { Minimum } \\
\text { Support }(\%)\end{array}$ & $\begin{array}{c}\text { Waktu } \\
\text { (detik) }\end{array}$ & $\begin{array}{c}\text { Jumlah 2-Frequent } \\
\text { itemset }\end{array}$ \\
\hline $2007-2009$ & 5.815 & 0.06 & 0.00 & 2 \\
$2010-2012$ & 10.605 & 0.04 & 0.03 & 7 \\
$2013-2015$ & 44.319 & 0.03 & 0.09 & 4 \\
$2007-2015$ & 60.738 & 0.02 & 0.23 & 8 \\
\hline
\end{tabular}

Tabel 8. Hasil rekomendasi dua buku periode 2007-2015 menggunakan algoritma Eclate

\begin{tabular}{|c|c|c|c|c|c|}
\hline \multirow{2}{*}{ Tahun } & \multicolumn{2}{|c|}{ Kode dan Judul Buku } & \multirow{2}{*}{$\begin{array}{l}\text { Support } \\
(\%)\end{array}$} & \multirow{2}{*}{$\begin{array}{c}\text { all- } \\
\text { confidence } \\
(\%)\end{array}$} & \multirow{2}{*}{$\begin{array}{c}\text { Jumlah } \\
\text { Ulangan } \\
\text { Pola }\end{array}$} \\
\hline & Pertama & Kedua & & & \\
\hline \multirow{8}{*}{$2007-2015$} & $\begin{array}{l}12311 \text { - Dasar-dasar } \\
\text { evaluasi pendidikan }\end{array}$ & $\begin{array}{l}42265 \text { - Pengantar } \\
\text { evaluasi pendidikan }\end{array}$ & 0.033 & 15.50 & 3 \\
\hline & $\begin{array}{l}6042 \text { - Anatomi } \\
\text { tumbuhan }\end{array}$ & $\begin{array}{l}6060 \text { - Anatomi } \\
\text { tumbuhan berbiji }\end{array}$ & 0.028 & 32.69 & - \\
\hline & $\begin{array}{l}6104 \text { - Anatomi dan } \\
\text { fisiologi manusia }\end{array}$ & $\begin{array}{l}6089 \text { - Anatomi dan } \\
\text { fisiologi untuk } \\
\text { pemula = anatomy } \\
\text { and physiology an } \\
\text { easy learner }\end{array}$ & 0.025 & 25.42 & 2 \\
\hline & $\begin{array}{l}17474 \text { - Farmakologi } \\
\text { : ulasan bergambar }\end{array}$ & $\begin{array}{l}17468 \text { - Farmakologi } \\
\text { dasar dan klinik : } \\
\text { Basic \& Clinical } \\
\text { pharmacology }\end{array}$ & 0.023 & 7.41 & 2 \\
\hline & 8858 - Biologi & $8864-$ Biologi & 0.023 & 12.06 & 2 \\
\hline & $\begin{array}{l}8265 \text { - Belajar } \\
\text { mudah } \\
\text { farmakologi }=(\text { Clinica } \\
1 \text { pharmacology: }\end{array}$ & $\begin{array}{l}17474 \text { - Farmakologi } \\
\text { : ulasan bergambar }\end{array}$ & 0.023 & 23.72 & 2 \\
\hline & $\begin{array}{l}53630 \text { - Psikologi } \\
\text { sosial }\end{array}$ & $\begin{array}{l}53631 \text { - Psikologi } \\
\text { sosial }\end{array}$ & 0.0214 & 32.50 & - \\
\hline & $\begin{array}{l}6088 \text { - Anatomi dan } \\
\text { Fisiologi untuk } \\
\text { Paramedis }\end{array}$ & $\begin{array}{l}59851 \text { - Struktur \& } \\
\text { Komponen: Tubuh } \\
\text { Manusia }\end{array}$ & 0.0214 & 13.40 & \\
\hline
\end{tabular}

